\title{
TPACK Confidence of Pre-service Teachers in Universiti Utara Malaysia
}

\author{
Arumugam Raman \\ Universiti Utara Malaysia \\ arumugam@uum.edu.my
}

DOI:10.5901/mjss.2014.v5n22p167

\begin{abstract}
The role of technology in education is undeniable (Niess, 2005). Teachers as moulders of human beings need to be skillful in integrating technology in education to deliver what they teach effectively. According to Malaysian Education Blueprint (2012) pre-service service teachers of Universiti Utara Malaysia are expected to master Information and Communication Technology (ICT) integration in the teaching and learning process (MOE, 2013). This study measures the level of Technological Pedagogical Content Knowledge (TPACK) outlined by Mishra and Koehler (2006). It includes seven knowledge dimensions, namely Content Knowledge (CK), Pedagogical Knowledge (PK), Technological Knowledge (TK), Pedagogical Content Knowledge (PCK), Technological Pedagogical Knowledge (TPK), Technological Content Knowledge (TCK), Pedagogical Content Knowledge (PCK) and Technological Pedagogical Content Knowledge (TPACK). This study involved 154 pre-service teachers from various programs such as a Bachelor's Degree in Education Majoring in Information Technology, Moral Education, Accounting and Business Management. Questionnaire forms were sent through a 'Google Form' to their respective emails and responses were analyzed using SPSS software. The findings showed that the pre-service teachers have a high level of competency, confidence and lastly TPACK. The test results have also shown that there is a significant difference between the male and female pre-service teachers regarding the confidence level in using ICT in teaching and learning as revealed by MANOVA analysis.
\end{abstract}

Keywords: Pre-service Teacher, Confidence, Competency, Gender, Information and Communication Technology (ICT), Technological Pedagogical Content Knowledge (TPACK).

\section{Introduction}

Universiti Utara Malaysia consists of three main colleges which are College of Business (COB-UUM), College of Arts and Science (CAS-UUM), and College of Law, Government and International Studies (COLGIS-UUM).College of Arts and Science consists of five (5) schools namely School of Computing, School of Education and Modern Languages, School of Multimedia Technology and Communication, School of Quantitative Science and School of Social Development. The School of Education and Modern Languages offers Bachelor in Education (B.Ed.) degrees specializing in Accounting, Business Management, Guidance and Counseling, Information Technology and Moral Education. The students' intake is monitored and sponsored by Ministry of Education. Upon completion, the pre-service teachers are posted in the government sponsored schools. While studying in the University, students are exposed to various technology based courses such as the multimedia software development course for education, animation and graphics in education, audio and video in education and education technology. All of these courses enable the graduates to apply technology when the teaching and learning process is implemented in the classrooms.

According to Malaysian Education Blueprint (2012) the ministry will ensure that all teachers meet a minimum level of Information and Communication Technology (ICT) literacy by the end of 2015. The system's standard for ICT literacy is based on an established rubric for ICT competency developed by the International Society for Technology in Education (ISTE, 2009); but ISTE is not designed to measure the ICT confidence for pre-service teachers. Therefore the management of the university should assess these pre-service teachers' TPACK to ensure that they are really ready to face the real world of education. Therefore, the Technological Pedagoical Content Knowledge (TPACK) framework is used to measure the level of confidence of pre-service teachers through the seven domains suggested by Mishra and Koehler (2006) as most suitable for pre-service teachers (Moersch, 2002; Albion, 2003; Schmidt et al, 2009). The researchers also measured the confidence and competency level of the pre-service teachers to ensure that all of them were able use technology in daily practice.

\section{Literature Review}


For the sake of assisting and guiding the researchers to integrate technology in education, scholars have developed several types of models or frameworks to integrate technology in education. Included among these models are Levels of Technology Integration (LoTI) (Moersch, 2002) scale, Apple Classrooms of Tomorrow (ACOT) continuum (Sandholtz, 1997), The North Central Regional Educational Laboratory (Lemke, 2003) model and International Society for Technology in Education (ISTE) NETS-T 2008 Standards (ISTE, 2008). Most of these integration models focus on general pedagogy terms, independent from specific domain content. However, now the technologists are of the opinion that the use of pedagogical technology is very much influenced by content domain. For instance, knowledge that is required to integrate technology in the science subjects is different than in geography subjects (Dorian, 2011).In the year 2006, a blueprint was suggested by blending three aspects of teachers' knowledge: Pedagogical Knowledge, Content Knowledge, and Technological Knowledge (Koehler \& Mishra, 2008; Mishra \& Koehlar, 2006). The new framework is known as Technological Pedagogical Content Knowledge (TPACK) (Thompson \& Mishra, 2007).

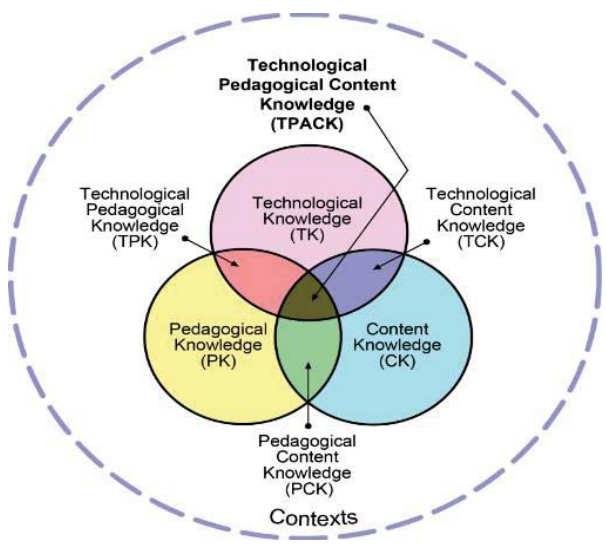

Figure 1. TPACK framework as suggested by Mishra \& Koehler (2006)

TPACK blueprint suggests seven different Categories of teachers' knowledge. Figure 1 shows the TPACK blueprint suggested by Mishra and Koehler (2006).The seven knowledge domains described by Mishra and Koehler (2006) include:

Pedagogical Knowledge or PK: Knowledge of the art of teaching, including methods, teaching techniques and strategies, classroom management skills, and planning teaching sessions. It also includes knowledge assessement and evaluation along with student learning (Koehler \& Mishra, 2005).

Content Knowledge or CK: Knowledge of subjects to be taught (eg, Physics, Chemistry, Geography). Shulman (1986) defines content knowledge as the knowledge of facts, concepts, and structure of a subject area, as well as the ways in which the truth and falsehood, and validity and invalidity within that content area, are established.

Technological Knowledge or TK: Knowledge of technology that constantly changes includes the ability to process information, communication, and solving problems in daily life and work. Koehler and Mishra (2008) define technological knowledge as a developed technology literacy where persons can broadly apply technology to their everyday lives, and recognize where technology can assist or impede the achievement of a goal.

Pedagogical Content Knowledge or PCK: Knowledge of the pedagogy or the teaching practices that are appropriate for a subject. This also includes knowledge of pedagogical methods, knowledge of the challenges any given area presents, as well as an understanding of students' preconceptions and misconceptions regarding a specific area content. Expertise in a particular area involves more than problem-solving skills and knowing the content (Bransford, Brown, and Cocking, 2000).

Technological Content Knowledge or TCK: Knowledge of the relationship between subjects and technology, including the knowledge related to appropriate technology to be used to explore a content area discipline. The choice of technologies affords and constrains the types of content ideas that can be taught. For example, an animated simulation may be useful in teaching language and arts concepts like grammatical rules. Furthermore, technological tools can provide a greater degree of flexibility in navigating across these representations (Koehler \& Mishra, 2008). 
Technological Pedagogical Knowledge or TPK: Knowledge for using technology to implement a teaching method. For example, TPK can be exhibited by knowing how to effectively use a digital camera in the classroom or knowledge of effective online teaching (Cox, 2008).

Technological Pedagogical Content Knowledge or TPACK: Knowledge of the complex interaction among content, pedagogy and technology.

\section{This study focuses on TPACK confidence among pre-service teacher in Universiti Utara Malaysia.}

Many researches have pertained to pre-service teachers who are confident with ICT and their abilities to use technology. For example, Owen and Moyle (2008) synthesized Markauskaite et al. (2006) research report whereby the pre-service teachers generally possessed good Instructional Technology or IT skills to use word processors and presentation softwares, be able to access and use email and the Internet, but less confident in using applications such as 'webgroup' discussions and website design. From their analysis, Owen and Moyle formulated a relationship between teachers' attitude and beliefs in determining their true practices and their abilities to learn new skills.

Research conducted by Albion (2003) emphasized an increasing trend to access computers and the Internet, but at the same time it also showed that this increasing access is also accompanied by an uneven level of confidence in the skills of the pre-service teachers. For example, even though there has been an improvement in basic IT skills, the use of database and spreadsheets remained relatively unchanged. Albion has also reported that website designs, online group discussions, virtual visits, data mining, and palmtop computers are rarely used.

There are several instruments to measure TPACK of teachers (Archambault \& Crippen, 2009; Jamieson-Proctor, Finger, \& Albion, 2010; Mishra \& Koehler, 2005; Schmidt et al., 2009). However, the instruments mentioned above have been designed to be used by in-service teachers. In the Schmidt et al. research, (2009) instruments were formulated to measure the TPACK level of pre-school pre-service teachers. Jamieson-Proctor, Finger, and Albion (2010) measured the level of TPACK of pre-service teachers regarding ICT courses. Schmidt et al. (2009) conducted the most comprehensive research that included most of the TPACK aspects regarding the education of pre-service elementary teachers.

\section{The research questions for this study are as follows:}

What is the competency level of pre-service teachers in using ICT applications?

What is the confidence level of pre-service teachers ICT usage?

What is the TPACK confidence level of the pre-service teachers in the Universiti Utara Malaysia?

\section{Method}

\section{Participants}

Altogether, 220 final semester students who were involved in this research were from the School of Education and Modern Language, Universiti Utara Malaysia. All of the students were under the Education Degree program with one of the following minors namely Accounting, Moral, Business Management or Information Technology.

\section{Instrument}

In this research three instruments were used based on the research questions that have been set. All three instruments were adapted from previous studies. The first instrument was used to measure the competency level of pre-service teachers in using ICT applications. Students were asked to evaluate their own competency level based on the 17 items provided using a 4-point Likert scale (Jamieson-Proctor, Finger, \& Albion, 2010). The second instrument was used to measure the confidence level of pre-service teachers in ICT. A Likert scale (4-point) was used to evaluate the confidence level of the pre-service teachers which are: 1-Not confident, 2- Quite confident, 3-Confidentand 4- Very confident. Twenty-three items from the ICT Audit Survey research (Watson et al., 2004) were used to measure the confidence level. Finally the students were asked to complete the online TPACK Confidence Survey in April 2013 voluntarily. Nineteen solid items in the questionnaire from Learning with ICT research: Measuring ICT use in the curriculum were adapted from Jamieson-Proctor et al. (2007) and its validity has been proven through the study conducted on measurement of technological knowledge (TK) and Pedagogical Knowledge (PK) (Albion, Jamieson-Proctor, \& Finger, 2010). 


\section{Instrument Validation}

A comprehensive study conducted by Schmidt et al. (2009) to develop and validate an assessment instrument for preservice teachers. They found the Cronbach's alpha statistics on the TPACK knowledge domains and factor analysis for each domain. Their results suggest that, with the modification and/or deletion of 18 of the survey items, the survey is a reliable and valid instrument that will help educators design longitudinal studies to assess preservice teachers' development of TPACK.

\section{Reliability of Instruments}

Alfa Cronbach was calculated to determine the internal consistency for every instrument and showed the following results: $\alpha=0.921$ (ICT application competency); $\alpha=0.922$ (Confidence in using ICT) and $\alpha=.9 .51$ (Technology, Pedagogy and Content).

\section{Data Collection Procedure and Analysis}

A time frame of two weeks was given to all students to answer the questionnaire sent through their respective e-mails (Google Form).The lecturers were informed to remind students to answer the questionnaire. Researchers had sent reminder emails to all students after a week. Data sent by students will be automatically saved in Google Drive. After the two week period ends data would have been processed using SPSS software.

\section{Results}

\section{Demographic Information}

A total of 154 students who are in the education degree program have answered the questionnaire. The response percentage is $70 \%$. Table 1 shows the respondents' details according to gender, degree program and the confidence level in using ICT in teaching and learning.

Table 1 Information for pre-service teachers, according to gender, program and confidence level in ICT

\begin{tabular}{lll}
\hline & Number of pre-service teachers & Percentage \\
\hline Gender: & 32 & 21.0 \\
Male & 122 & 79.0 \\
Female & 154 & 100 \\
\hline Total & & \\
\hline Program: & 27 & 17.5 \\
Bachelor in Education (Accounting) & 36 & 23.5 \\
Bachelor in Education (Business Management) & 17 & 11.0 \\
Bachelor in Education (Guidance and Counseling) & 48 & 31.4 \\
Bachelor in Education (Information Technology) & 26 & 16.6 \\
Bachelor in Education (Moral Education) & 154 & 100 \\
\hline Total & & 2.6 \\
\hline Level of Confidence in Using ICT: & 4 & 28.6 \\
Not Confident & 44 & 42.8 \\
Quite Confident & 66 & 26.0 \\
Confident & 40 & \\
Very Confident & &
\end{tabular}


Table 1 shows that $79 \%$ of respondents were females. This is in line with the trend in the teaching profession in Malaysia. The response percentage for the Bachelor Degree (Information Technology) program is high (31\%) because the researchers are teaching staff for courses related to information technology. Whereas the response from the Bachelor Degree (Guidance and Counseling) group was low because the researchers did not have much access to this group due to time constraint. The level of confidence in ICT was very encouraging with quite confident $(28.6 \%))$, confident $(45.4 \%)$ ) and very confident (21.5\%).

\section{Competency Level of Using ICT Application}

Table 2 shows a number of applications requested by respondents to evaluate their individual competency levels; mean (with standard deviation) for each application.4-point Likert Scale was used:1=Not Competent, 2=Quite Competent, 3=Competent, 4=Very Competent. Data was analyzed using SPSS V17 software.

Table 2 Competency of pre-service teachers in using ICT applications

\begin{tabular}{llll}
\hline Item & ICT Application Software & $\bar{X}(\mathrm{SD})$ & \%Not \\
& & & .7 \\
\hline 1 & Word processing (Egs. Microsoft word) & $3.51(.87)$ & 18.3 \\
2 & Desktop Publishing (Egs: Microsoft Publisher) & $2.76(1.21)$ & 1.5 \\
3 & Presentation Software (Egs: Microsoft Powerpoint) & $3.26(.84)$ & 8.5 \\
4 & Electronic spreadsheet (Egs: Microsoft Egscel) & $2.75(.98)$ & 42.5 \\
5 & Database (Egs: Microsoft Access) & $1.65(.86)$ & 29.4 \\
6 & Graphic Creation and / or editing Egs: Adobe Photoshop, Paint) & $2.03(.52)$ & 6.5 \\
7 & Capture Digital Image (Egs: Digital Cameras, Scanning) & $2.75(1.02)$ & 60.9 \\
8 & Multimedia development and composition (Egs:Flash, Director) & $1.68(.98)$ & 51.3 \\
9 & Digital Video Editing (Egs: Adobe Premire, Movie Director) & $1.76(1.05)$ & .1 \\
10 & Email (Egs: Gmail, Yahoo, Microsoft Outlook) & $3.75(.78)$ & 1.1 \\
11 & Web Browser (Egs:Internet Egsplorer, Google Chrome, Safari, Firefox) & $3.42(.85)$ & .3 \\
12 & Web Search (Eg: Google) & $3.5(.76)$ & 55.2 \\
13 & Web page development (Eg. Dreamweaver) & $1.56(1.09)$ & 6.5 \\
14 & Web 2.0 and Social Network (Egs: Facebook, Flickr, Twitter, Youtube) & $3.15(.95)$ & 25.6 \\
15 & Online learning (Eg: Moodle) & $2.21(.65)$ & 19.5 \\
16 & Online publishing (Eg: Blog, Podcast, Youtube) & $2.82(1.02)$ & 42.3 \\
17 & Create reusable learning objects & $1.65(1.0)$ & \\
\hline
\end{tabular}

On the whole, these results show that the UUM pre-service teachers are skillful in using basic ICT applications needed to equip them as teachers in the 21st century. As shown in Table 2, the mean score for the use of Microsoft applications such as word processing $(\bar{X}=3.51)$, presentation $(\bar{X}=3.26)$, email $((\bar{X}=3.75)$, web browser $(\bar{X}=3.42)$, web search $(\bar{X}=3.50)$, web 2.0 and social network $(\bar{X}=3.15)$ was very high compared to using desktop publishing software $(\bar{X}=2.76)$, database $(\bar{X}=1.65)$, multimedia development and composition $(\bar{X}=1.68)$, digital image and video processing $(\bar{X}=2.75$, and $(\bar{X}=1.76)$, web page development $(\bar{X}=1.56)$ and creating reusable learning objects $(\bar{X}=1.65)$. It can be said that the UUM pre-service teachers are able to use basic ICT software very well but unfortunately their ability in using the 'High hand' (required high IT skills) software is unsatisfactory. Online learning $(\bar{X}=2.21)$ showing a low confidence level with a percentage of $25.6 \%$ indicated that they are not confident in using it. This might be because the importance of using 'Moodle' was not emphasized 
enough at the college level (Arumugam, 2013). Apart from that, the web page development also showed that the percentage of not competent was quite high, $55.2 \%$. This phenomenon might be due to the impression among pre-service teachers that they are not trained to become web page developers but to use it instead. However, the web page development course became one of the contributors to the findings for item 13 .

\section{Confidence Level of ICT Usage}

The Chi-square test was used to investigate the relationship among the frequencies of various categories (Burns, 1990, p.153). The test results have also shown that there is a significant difference between the male and female pre-service teachers regarding the confidence level in using ICT in teaching and learning, $X 2(3, N=154)=15.21, p=.001$. The female pre-service teachers (48.5\%) show quite or no confidence compared to the male pre-service teachers who only $3.1 \%$. Table 3 shows the frequency for each male and female category.

Table 3 The confidence level frequencies of pre-service teachers in using ICT in teaching and learning

\begin{tabular}{llll}
\hline \multirow{2}{*}{ Level } & \multicolumn{2}{l}{ Gender } & \%Total \\
\cline { 2 - 3 } & $\%$ Female(N) & \%Male(N) & 2.6 \\
\hline Not confident & $3.3(4)$ & $0(0)$ & 28.6 \\
Quite Confident & $35.2(43)$ & $3.1(1)$ & 42.8 \\
Confident & $45.9(56)$ & $31.3(10)$ & 26.0 \\
Very Confident & $15.6(19)$ & $65.6(21)$ & 100 \\
\hline Total & $100(122)$ & $100(32)$ & \\
\hline
\end{tabular}

The confidence levels in using ICT teaching and learning according to programs also show significant differences, $X 2$ (12, $\mathrm{N}=154)=52.16, p=.000$. The findings are shown in Table 4. Data in Table 4 shows that the group of students from the Bachelor of Education (Information Technology) program is more confident compared to other groups of students. The group of students from the Bachelor of Education (Guidance and Counseling) program shows the lowest level of confidence.

Table 4 Confidence level in using ICT in teaching and learning according to program

\begin{tabular}{|c|c|c|c|c|c|}
\hline Program & $\begin{array}{l}\text { Not } \\
\text { confident } \%\end{array}$ & $\begin{array}{l}\text { Quite } \\
\text { Confident\% }\end{array}$ & Confident $\%$ & $\begin{array}{l}\text { Very } \\
\text { Confident } \%\end{array}$ & Total\% \\
\hline Bachelor in Education (Accounting) & 3.5 & 33.3 & 45.0 & 18.2 & 100 \\
\hline Bachelor in Education (Business Management) & 1.5 & 21.4 & 53.3 & 23.8 & 100 \\
\hline $\begin{array}{l}\text { Bachelor in Education (Guidance and } \\
\text { Counseling) }\end{array}$ & 14.5 & 22.5 & 50.0 & 13.0 & 100 \\
\hline Bachelor in Education (Information Technology) & 4.5 & 35.0 & 36.0 & 24.5 & 100 \\
\hline Bachelor in Education (Moral Education) & 1.6 & 25.5 & 52.5 & 20.4 & 100 \\
\hline
\end{tabular}

\section{Confidence in Using ICT- Technological Pedagogy Content Knowledge (TPACK)}

Table 5 shows the TPACK confidence level of the pre-service teachers in the Universiti Utara Malaysia. A total of 19 items was used according to the TPACK confidence level of the pre-services from the UUM School of Education. The first 13 items (First dimension) consisted of instrument upgrading factors and the other 6 items (Second dimension) consisted of transformation factors. The table also shows examples of ICT integration and the percentage of those who assume that they do not have confidence or they have limited confidence to support students to use ICT for every TPACK example. 
Table 5 Confidence to integrate ICT in learning -TPACK

\begin{tabular}{|c|c|c|c|}
\hline Item & I can help students in using ICT in the classroom to: & $\bar{X}(\mathrm{SD})$ & $\begin{array}{l}\text { \% No/ } \\
\text { Limited } \\
\text { Confidence }\end{array}$ \\
\hline 1 & gain knowledge, skills, capabilities, and attitude to work continuously & $2.38(.85)$ & 35.2 \\
\hline 2 & $\begin{array}{l}\text { develop functional competency in the curriculum field that has been } \\
\text { determined. }\end{array}$ & $2.45(.95)$ & 33.2 \\
\hline 3 & synthesize their knowledge. & $2.72(.98)$ & 41.0 \\
\hline 4 & $\begin{array}{l}\text { active in constructing their own knowledge in cooperating with their friends } \\
\text { and others }\end{array}$ & $\begin{array}{l}2.65 \\
(1.00)\end{array}$ & 28.0 \\
\hline 5 & active in constructing knowledge that integrates the curriculum field. & $2.56(.85)$ & 32.2 \\
\hline 6 & $\begin{array}{l}\text { construct in depth understanding interesting topics related to the curriculum } \\
\text { field that is studied. }\end{array}$ & $2.72(.85)$ & 34.8 \\
\hline 7 & develop scientific understanding of the world. & $2.45(.95)$ & 39.5 \\
\hline 8 & give motivation for curricular tasks. & $2.75(.92)$ & 28.4 \\
\hline 9 & plan and / or manage curricular projects. & $2.60(.85)$ & 23.1 \\
\hline 10 & integrate different media to create appropriate products. & $2.50(.80)$ & 39.8 \\
\hline 11 & support learning process elements. & $2.65(.95)$ & 36.0 \\
\hline 12 & demonstrate what they have learned. & $2.85(.78)$ & 20.5 \\
\hline 13 & carry out formative / or summative assessments. & $2.72(.96)$ & 29.5 \\
\hline 14 & be made aware of the global implication of ICT based technology on societies. & $2.50(.85)$ & 38.5 \\
\hline 15 & gain intercultural understanding. & $2.61(.75)$ & 36.5 \\
\hline 16 & assess themselves and society values critically. & $2.45(.90)$ & 42.0 \\
\hline 17 & communicate with others in and at global level. & $\begin{array}{l}2.75 \\
(1.00)\end{array}$ & 30.4 \\
\hline 18 & $\begin{array}{l}\text { get involved in independent learning through access to education at their own } \\
\text { time, place and pace. }\end{array}$ & $2.75(.99)$ & 32.5 \\
\hline 19 & understand and get involved in the changing knowledge economy. & $\begin{array}{l}2.50 \\
(1.05)\end{array}$ & 42.5 \\
\hline
\end{tabular}

\section{Gender Differences}

The Pearson Chi-square significance test revealed no significance with each of the 19 items. Gender impact, however, on the confidence level of the pre-service teachers in this study was significant. This result is in line with studies conducted by previous researchers. MANOVA was used to determine whether gender is the determining factor in their confidence level to integrate ICT in the students' future learning, in line with the research hypothesis to measure TPACK. The MANOVA was significant for gender, Pillai Trace $=.02, F=3.17, \mathrm{df}=(2,151), p=.000$, indicated the different levels of confidence to support student ICT use for male and female teachers. However, the main effect is of no significance as the univariate $F$ tests showed no significant difference between males and females for either dimensions. Table 6 shows the means (with standard error) for each factor by gender.

Table 6 Comparison between the means of male and female pre-service teachers for two ICT dimensions used by students $(\mathrm{N}=154)$

\begin{tabular}{lll}
\hline Gender & Dimension 1 & Dimension 2 \\
\hline & & 173
\end{tabular}




\begin{tabular}{lll}
\hline & (Increase learning outcome) & ( Transform learning outcome) \\
\hline Female & $2.71(.07)$ & $2.47(.05)$ \\
& $2.46(.12)$ & $2.45(.34)$ \\
\hline
\end{tabular}

This research shows that there was no difference in terms of gender. Therefore, it can be concluded that there is no difference between male and female pre-service teachers in terms of confidence in integrating ICT based on TPACK.

\section{Discussion}

This research explores basic aspects of ICT knowledge of students in final semester as pre-service teachers under the education program in Universiti Utara Malaysia. It was found that the level of broadband and ICT access among students was high. Generally, the pre-service teachers stated a high level of interest and usage of ICT either for personal usage or for professional purposes. The pre-service teachers also voiced their intention to use ICT to improve learning outcomes compared to using ICT in teaching and learning.

TPACK is a multi-dimensional construct that can provide pre-service teachers a framework to address technology integration in instruction. The results from this study indicated that the TPACK survey was reliable and valid. The Ministry of Education goals will not be achieved if TPACK is ignored because the framework provides important directions in supporting pre-service teachers in developing the ability and confidence to teach with technology. Using TPACK as a framework for decision-making, a teacher program provide better guidance for pre-service teachers towards gaining an understanding of the holistic concept of pedagogy, content, and technology and thus eventually improving the teaching and learning process in classroom.

This research also found a small change in ICT software usage competency compared to previous studies (Albion, 2003). Previous studies showed a high mean level $(\bar{X} \geq 3)$ in the use of word processing software, presentation, e-mails, web browsers, web search; and lower mean level $(\bar{X} \leq 3)$ for web application 2.0 which evolved over a few years ago. The study also revelaed a low mean about using web 2.0, multimedia, and digital video. This result is likely due to the lack of facilities available to the students. As most of these applications (web 2.0, multimedia, digital video editing) need high speed computers and Internet access. The students may feel not competent to use these technologies in instruction. Since 2003 a significant fund was channeled into the development of learning objects (www.moe.gov.my/btp).

This research, having a similar purpose as the previous related studies, found that there is a difference in terms of gender and confidence in using ICT in teaching and learning. However, this research shows that there is a positive trend among female pre-service teachers in terms of confidence in using ICT. The difference can be seen in the programs offered. Looking at the program structure of the School of Education, this might happen because of limited need for ICT usage for the courses without ICT components. For example, students from B. Ed (IT) program (Very Confident - 24\%) have a very high level of confidence compared to students from B. Ed (Guidance and Counseling) program (Very confident - 13.0\%).

Finally, this research measures two dimensions of TPACK of pre-service teachers which are: 1) learning outcome improvement dimension and ii) transformation dimension. Research findings are different than previous studies whereby in this study there is no difference in terms of gender.

In general, this research exhibits ICT experience of pre-service teachers in the school of education in UUM. The uniqueness of this study is that it measured confidence, competency and TPACK level of pre-service teachers. Since there are 27 Teacher Training Institutes and few universities offering B. Ed program around Malaysia this study recommends that teacher education programs need to be audited using the TPACK model as the evaluation lens so that the auditing process for integrating technology in education can be easily implemented according to Malaysia Education Blueprint.

\section{References}

Albion, P. (2003). Graduating Teachers' Dispositions for Integrating Information and Communications Technologies into Their Teaching. In C. Crawford et al. (Eds.), Proceedings of the Society for Information Technology and Teacher Education International Conference 2003, pp. 1592-1599. Chesapeake, VA:Association for the Advancement for Computing in Education (AACE). 
Albion, P., Jamieson-Proctor, R., \& Finger, G. (2010). Auditing the TPACK Competence and Confidence of Australian Teachers: The Teaching With ICT Audit Survey (TWictAS). Paper presented at the Societyfor Information Technology and Teacher Education Conference (SITE), San Diego, California, March 29-April 2, 2010.

Archambault, L., \& Crippen, K. (2009). Examining TPACK among K-12 online distance educators in the United States, Contemporary Issues in Technology and Teacher Education, 9(1).

Arumugam, R. (2013) Pre-service teachers' acceptance of Learning Management Software: An application of the UTAUT2 Model, International Education Studies, 6 (7).

Bransford, J., Brown, A., \& Cocking, R. (Eds.). (2000). How People Learn: Brain, Mind, Experience, and School (Expanded Ed). Washington, DC: National Academy Press.

Dorian, S. (2011). Technological Pedagogical Content Knowledge: Secondary School Mathematics Teachers' Use of Technology, (Unpublished doctoral thesis), University of Toronto, Canada

International Society for Technology in Education. (2008). National Educational Technology Standards for Teachers: Second Edition. Eugene, OR: ISTE.

Jamieson-Proctor, R. M., Watson, G., Finger, G., Grimbeek, P., \& Burnett, P.C. (2007).Measuring the Use of Information and Communication Technologies (ICTs) in the Classroom. Computers in the Schools, 24(1/2), 167-184.

Jamieson-Proctor, R., Finger, G., \& Albion, P. (2010). Auditing the TK and TPACK confidence of pre-service teachers: Are they ready for the profession? Australian Educational Computing, 25(1), 8-17.

Koehler, M., \& Mishra, P. (2008). Introducing TPCK. In AACTE Committee on Innovation and Technology, Handbook of Pedagogical Content Knowledge (TPCK) for Educators. New York: Routledge/Taylor \& Francis Group.

Lemke, C. (2003). Standards for a modern word: Preparing students for their future. Learning \& Leading with Technology, 31 (1), 6-9.

Markauskaite, L., Goodwin, N., Reid, D., \& Reimann, P. (2006). Modelling and evaluating ICT courses for pre-service teachers: What works and how it works? In Informatics Education - The Bridge between Using and Understanding Computers, 242-254, Heidelberg, Springer.

Ministry of Education, (2012). Malaysia Education Blueprint 2013 - 2025. Percetakan Nasional Malaysia Berhad: Kuala Lumpur

Niess, M. L. (2005). Preparing teachers to teach science and mathematics with technology: Developing a technology pedagogical content knowledge. Teaching and Teacher Education, 21(5), 509-523.

Mishra, P., \& Koehler, M. J. (2006). Technological pedagogical content knowledge: A framework for teacher knowledge. Teachers College Record, 108(6), 1017-1054.

Moersch, C. (2002). Measures of success: Six instruments to assess teachers' use of technology. Learning \& Leading with Technology, 30(3), 10-13, 24.

Owen, S., \& Moyle, K. (2008).Students' Voices Learning with Technologies Students' expectations about learning with technologies: A literature review. University of Canberra.

Sandholtz, J. H. (1997). Teaching with technology: Creating student-centered classrooms. New York, NY: Teachers College Press.

Schmidt, D. A., Baran, E., Thompson, A. D., Mishra, P., Koehler, M. J., \& Shin, T. S. (2009). Technological Pedagogical Content Knowledge (TPACK): The Development and Validation of an Assessment Instrument for Preservice Teachers. Journal of Research on Technology in Education, 42(2).

Roblyer, M. D. \& Schwier, R. (2003). Intergrating educational technology into teaching.Toronto: Prentice Hall.

Thompson, A. D., \& Mishra, P. (2007). Breaking news: TPCK becomes TPACK. Journal of Computing in Teacher Education, 24(2), 38, 64. 